\title{
AN APPROACH TO POSITIONAL QUALITY CONTROL METHODS FOR AIRBORNE INSAR HIGH-RESOLUTION X-BAND ORTHOIMAGES AND P-BAND DIGITAL TERRAIN MODEL \\ Uma abordagem de métodos de controle de qualidade posicional para modelos digitais de terreno de banda $P$ e ortoimagens de banda $X$ de alta resolução de radar interferométrico (InSAR) aerotransportado
}

\author{
Gleice Pereira da Silva ${ }^{1,2}$ - ORCID: 0000-0002-9622-0352 \\ Roberto Quental Coutinho² - ORCID: 0000-0003-0471-3908
}

Rafael Antonio da Silva Rosa ${ }^{3}$ - ORCID: 0000-0002-1324-4077

\begin{abstract}
${ }^{1}$ Universidade Federal de Pernambuco, Programa de Pós-Graduação em Engenharia Civil, Recife - PE, Brasil. E-mail: robertoqcoutinho@gmail.com
\end{abstract}
${ }^{2}$ Instituto Federal de Educação Ciência e Tecnologia de Pernambuco, Campus Abreu e Lima, Abreu e Lima - PE, Brasil. E-mail: gleice750@gmail.com

${ }^{3}$ Visiona Tecnologia Espacial S.A., São José dos Campos - SP, Brasil.

E-mail: rafael.rosa@visionaespacial.com.br

Received in $12^{\text {th }}$ December 2019

Accepted in $1^{\text {st }}$ November 2020

\begin{abstract}
:
The positional validation of datasets is an important step for cartography studies since it allows learning about its accuracy, and also indicates the data process quality. However, the positional validation of Synthetic Aperture Radar (SAR) datasets have some additional challenges when compared to optical images due to the geometric distortions. We employ existing targets such as traffic signs and lampposts in the scene and identify them on the image as control points. We performed the validation of the geographic coordinates used as planialtimetric positional control points, using both the amplitude backscattering orthoimage and the Digital Terrain Model (DTM) generated from the InSAR system. We employed the NMAS, ASPRS and NSSDA tests along with information by the Brazilian Standards. This validation showed these control points presented the following results for 1:10,000 scale: NMAS test - class " $A$ " in PEC and PEC-PCD; ASPRS test $-R M S E_{x}=1.317 \mathrm{~m}, R M S E_{y}=1.231 \mathrm{~m}$ and $R M S E_{z}=1.145 \mathrm{~m}$; and NSSDA test $-R M S E_{r}=1,802 \mathrm{~m}$, Precision $_{r}=3.118 \mathrm{~m}$ and Precision $_{z}=2.244 \mathrm{~m}$. These results prove we can use the proposed targets as control points and the used InSAR datasets meet the expected quality for generation of geotechnic products for 1:10,000 scale.
\end{abstract}

Keywords: SAR Dataset, Positional Validation, Accuracy Test, Brazilian Standardization, NMAS, ASPRS and NSSDA.

How to cite this article: SILVA, G. P.; ROSA, R. A. S. An approach to positional quality control methods for airborne INSAR highresolution x-band orthoimages and p-band digital terrain model. Bulletin of Geodetic Sciences. 27(1): e2021001, 2021. 


\section{Resumo:}

A validação posicional de conjuntos de dados é uma etapa importante para os estudos de Cartografia, pois permite conhecer sua precisão, além de indicar a qualidade do processamento dos dados. No entanto, em se tratando de dados de Radar de Abertura Sintética (SAR), essa validação apresenta alguns desafios adicionais quando comparada à de imagens ópticas, devido às distorções geométricas. Utilizou-se alvos existentes, como placas de trânsito e postes de luz presentes na cena e os identificando na imagem como pontos de controle. Realizou-se a validação das coordenadas geográficas utilizadas como pontos de controle posicional planialtimétrico, utilizando tanto a ortoimagem de retroespalhamento de amplitude quanto o Modelo Digital de Terreno (MDT) gerados a partir do sistema InSAR. Empregou-se os testes NMAS, ASPRS e NSSDA juntamente com informações das Normas Brasileiras. Os resultados dos testes para a escala 1:10.000 foram: o teste NMAS - classe "A" no PEC e no PEC-PCD; o teste ASPRS - RMSE $=1,317 \mathrm{~m}, R M S E_{y}=1,231 \mathrm{~m}$ e $R M S E z=1,145 \mathrm{~m}$; e o teste NSSDA - RMSEr $=1,802 \mathrm{~m}$, Precision $r=$ $3,118 \mathrm{~m}$ e Precision $_{z}=2,244 \mathrm{~m}$. Esses resultados comprovam que pode-se utilizar os alvos propostos como pontos de controle e que os conjuntos de dados InSAR utilizados atendem à qualidade esperada para a geração de produtos geotécnicos para a escala 1:10.000.

Palavras-chave: Conjunto de dados SAR, validação posicional, teste de precisão, padronização brasileira, NMAS, ASPRS e NSSDA.

\section{Introduction}

The radar system transmits electromagnetic pulses that propagate in space, which, when touching an obstacle (object), returns to the receiving antenna (Curlander and McDonough 1991; Franceschetti and Lanari 2018), gaining ground for cartography. This system has the following advantages: it is economically viable because of its cloud-view characteristics and can be used at any time of the day (active sensor) and under all weather conditions; it can be used in areas with vegetation, because its signal goes through foliage (Rosa, 2004; Gaboardi and Lübeck, 2016); and it provides the following datasets: Pand X-Band Orthoimages, Color Orthoimages, Digital Surface Model (DSM), and Digital Terrain Model (DTM), which can be utilized in Geotechnics, that uses the cartographic base generated from information as of the orthoimage and the DTM, for the preparation of its thematic maps, for instance, slope maps, shaded reliefs, among others.

These thematic maps mentioned above are widely used and require the cartographic base to have known positional quality. Thus, in 2014, the remote sensing SAR (Synthetic Aperture Radar) with the technology "Synthetic Aperture Radar Interferometry (InSAR)" were used in the preparation of products for the Geotechnical area, through the "geotechnical charts" project, which was an agreement between the Geotechnical Hillside, Plains and Disasters Engineering Group (GEGEP) - UFPE and the Ministry of Cities. One of the objectives of this project was positional validation of SAR derived products as orthoimage and DTM dataset, which will be discussed in Section 2.2. This dataset was not positionally validated, therefore, it was necessary to verify if it was in accordance with the current Brazilian cartographic norms.

Positional quality control allows assessing the positional quality ofcartographic inputs and is widely used, as shown by Galo \& Camargo (1994); Maranhão (2013); Pereira \& Nero (2015); Milagros (2018); Farias et al. (2018); and Arcanjo \& Anjos (2019).

In the context of the project mentioned above, Silva (2020) identified targets in the study area that could be used as a positional control point in the validation of SAR data. The municipality of Cabo Santo Agostinho, studied in the research, did not have validated data for this acquisition scale. During the aforementioned research, difficulties / disadvantages were found in the choice of features that were identified in the orthography and in the field in relation to the planimetry of the points. These difficulties are a consequence of the orthoimage being presented 
in gray scale, thus resulting in radiometric and geometric distortions, as well as several points with pixel explosions within the study area, making it almost impossible to visualize and identify the elements contained in the area.

Normally, photoidentifiable targets are used as control points, such as buildings, corners or corners of streets, roads or avenues, among others. These points work very well for optical images, however, the same does not happen on radar images due to the geometric distortions of its lateral view (Rosa, 2017b). The objective of this work is precisely to test the use of these control points mentioned above and, with them, to validate the planialtimetric positional quality of the InSAR data. The following points were used in the dataset: the Orthoimage, generated from the X-band planimetric validation and the Digital Terrain Model (DTM) altimetric validation, generated from the P-band. Both were acquired by Embraer's OrbiSAR airborne system, in 2014, in Cabo de Santo Agostinho - PE region, Brazil. Thus, to validate this dataset, the points chosen as planialtimetric positional control points were used, applying the NMAS (National Map Accuracy Standard), ASPRS (American Society of Photogrammetry and Remote Sensing) and NSSDA (National Standard for Spatial Data Accuracy) tests (Ariza, 2002) on the $X, Y$ and $Z$ axis.

\section{Methodology}

The entire methodology is illustrated in Figure 1. It consists of positionally validating the control points, using NMAS, ASPRS and NSSDA statistical tests in SAR orthoimage and DTM data, using metal structure such as traffic signs and lamppost as control points. Therefore, the first step is to define the study area for positional validation; secondly, the planialtimetric positional control points are chosen; In the third stage, statistical tests are applied to the research data; and finally, the results and the analysis of the research are presented.

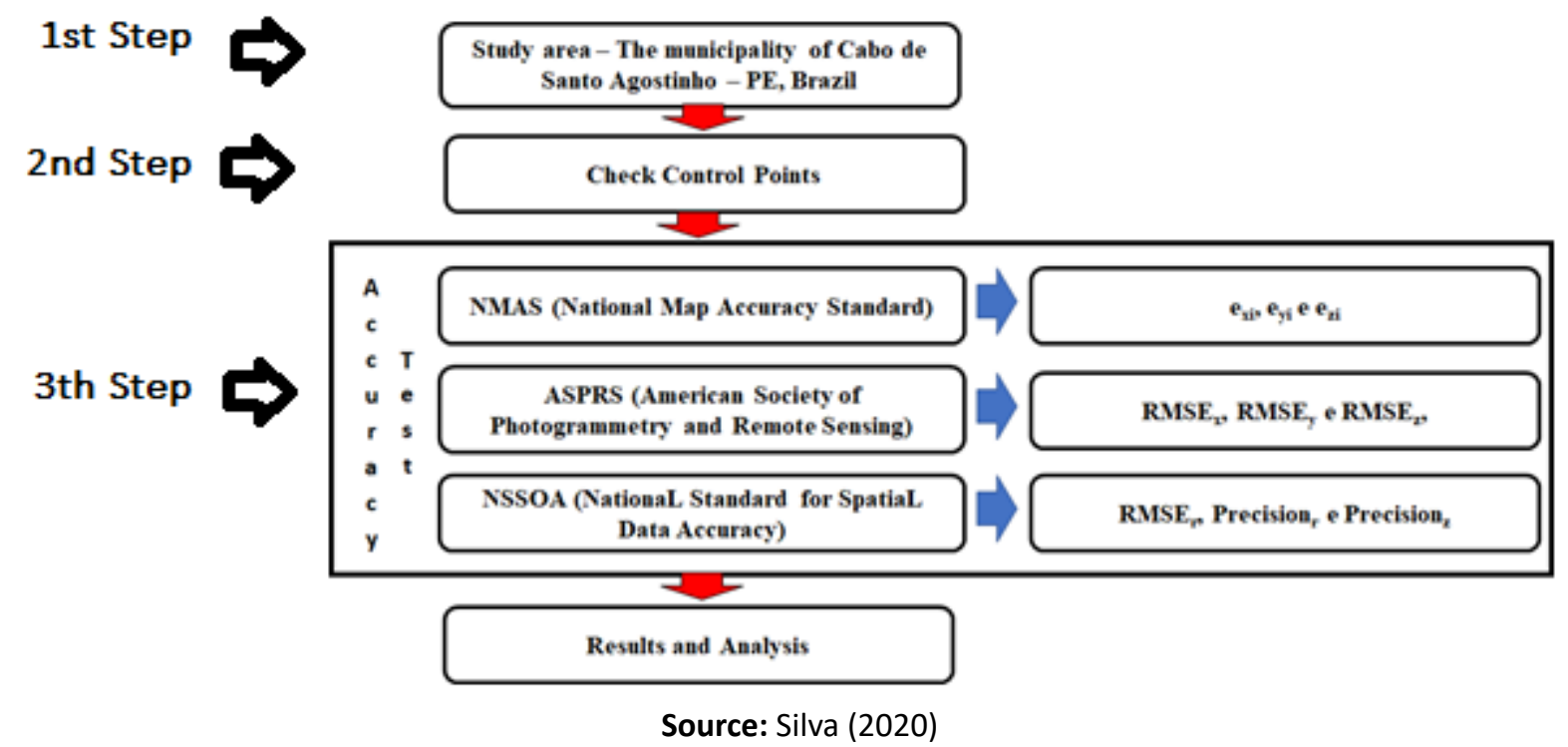

Figure 1: Flowchart of the proposed methodology for positional validation of planialtimetric positional control points.

\subsection{Study area}

The study area is located in the municipality of Cabo de Santo Agostinho, Pernambuco State, Brazil, with total area of $448.74 \mathrm{~km}^{2}$, equivalent to $16.28 \%$ of the Recife Metropolitan Region (RMR). The approximate central geographic coordinates are $8^{\circ} 17^{\prime} 15^{\prime \prime} \mathrm{S}$ and $35^{\circ} 02^{\prime} 00^{\prime \prime} \mathrm{W}$ an elevation above sea level of $30 \mathrm{~m}$. The chosen study area 
has $97 \mathrm{~km}^{2}$, which represents approximately $21.60 \%$ of the surface of the municipality of Cabo de Santo Agostinho as illustrated in Figures 2 and 3.

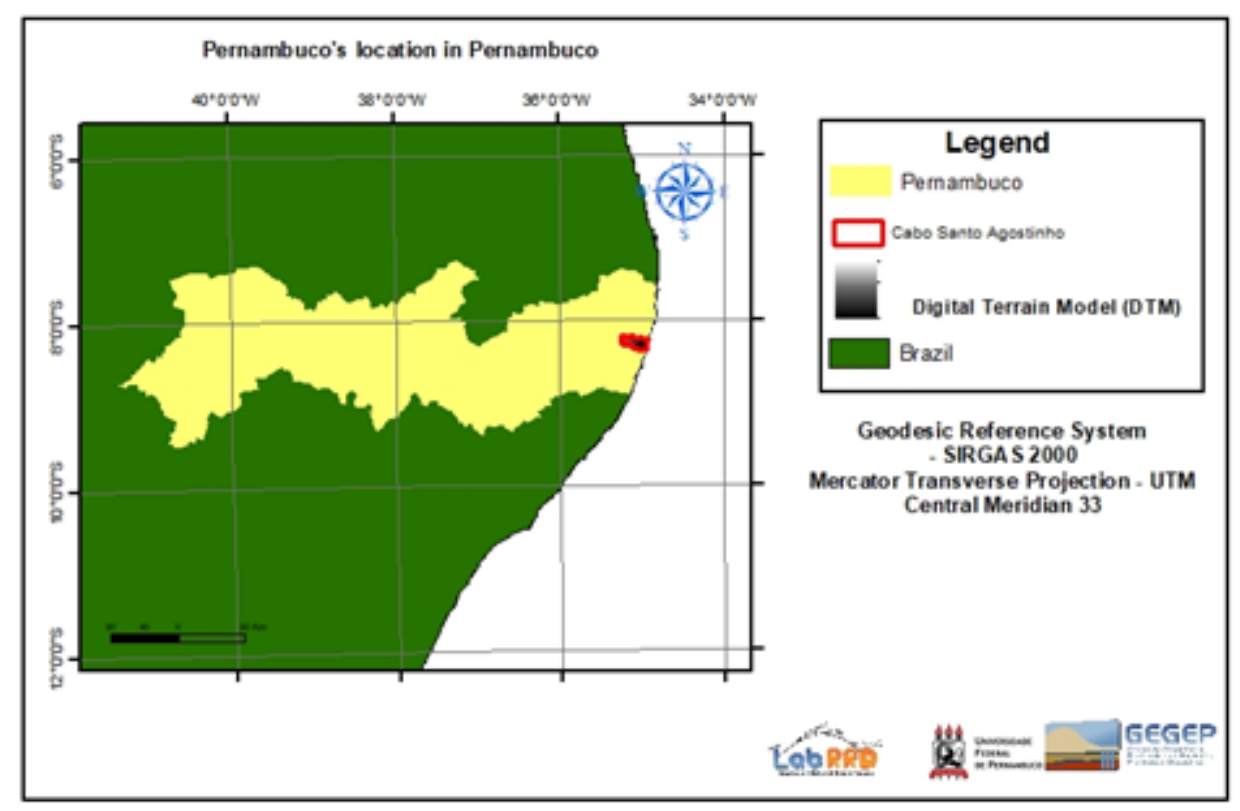

Source: Silva (2020)

Figure 2: The study area within the state of Pernambuco.
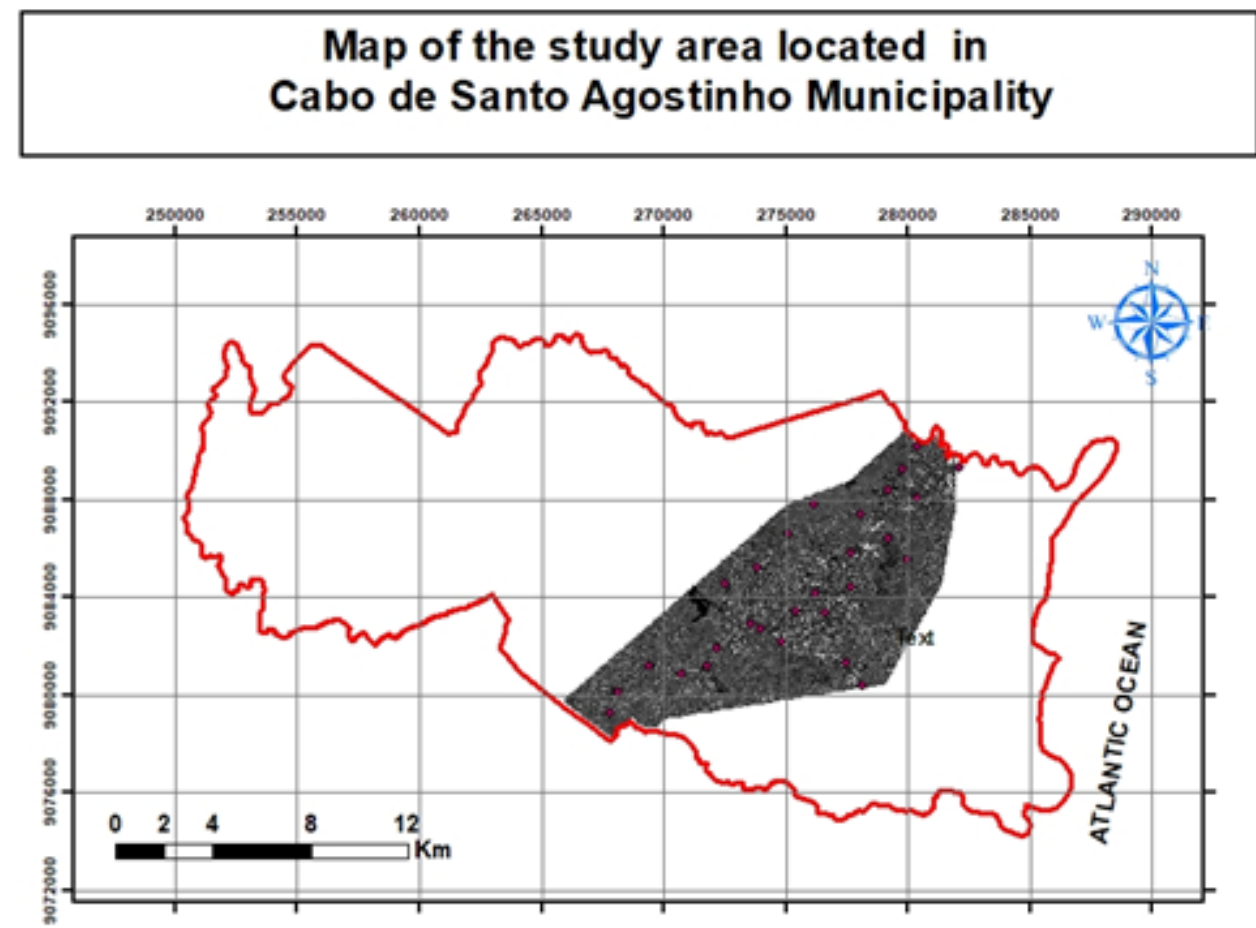

Source: Silva (2020)

Figure 3: The study area within the municipality of Cabo de Santo Agostinho. 


\subsection{Materials}

The orthoimage (Figure 4.a) and Digital Terrain Model (DTM) (Figure 4.b) used were acquired by Embraer's OrbiSAR-2 airborne system (Figure 5) at a flight altitude of $6086.62 \mathrm{~m}$, in January of 2014, in the region of Cabo de Santo Agostinho - PE, Brazil, on a scale of 1: 25.000 , and subsequently reprocessed to a scale of 1: 10.000 . The orthoimage was acquired in the X-band $\left(9.6 \mathrm{GHz}, 3 \mathrm{~cm}\right.$ wavelength) with $400 \mathrm{MHz}$ bandwidth, $20^{\circ}$ off-nadir angle, $14 \mathrm{~km}$ swath width, $1.5 \mathrm{~m} \times 1.5 \mathrm{~m}$ pixel size and $0.5 \mathrm{~dB}$ radiometric resolution (Moreira, 1992), and 16 bits; and the DTM acquired in the P-band (400.3 MHz, $75 \mathrm{~cm}$ wavelength) with $100 \mathrm{MHz}$ bandwidth, $10^{\circ}$ off-nadir angle, $14 \mathrm{~km}$ swath width, $1.5 \mathrm{~m} \times 1.5 \mathrm{~m}$ pixel size and $1.4 \mathrm{~m}$ elevation resolution 32 bits. The DTM (Figure $4 . \mathrm{b}$ ) used was generated from the P-band by the product supplier company. Therefore, no artificial technique was used to generate the DTM because the $\mathrm{P}$-band crosses the vegetation, providing real information of the terrain, that is, below the vegetation.

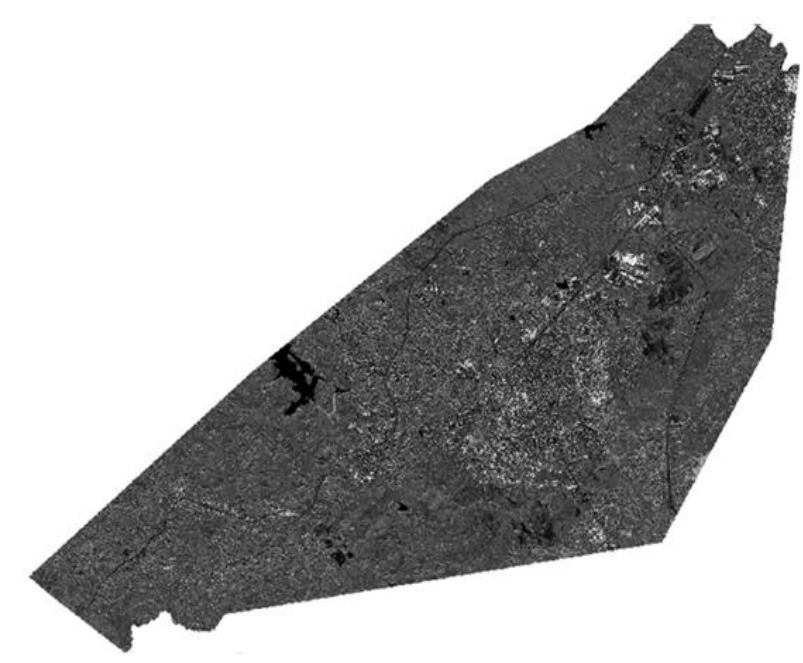

(a)

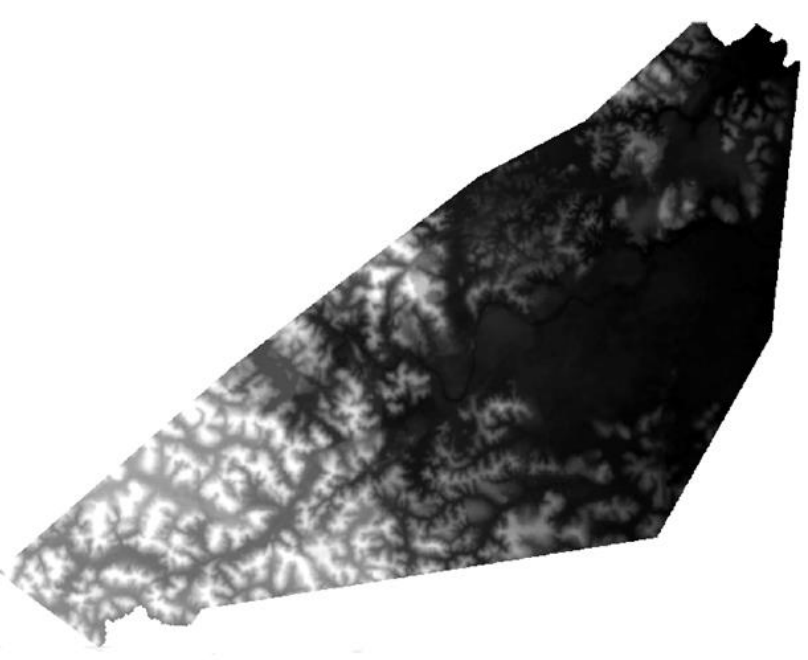

(b)

Source: Silva (2020)

Figure 4: The InSAR dataset used for planimetric positional validation: a) System-based orthoimage; b) DTM.

The OrbiSAR-2 airborne uses the Global Positioning System (GPS) + Inertial Measurement Unit (IMU) Applanix set, which provides $5 \mathrm{~cm}$ positional accuracy ( $X, Y$ and $Z$ ), guaranteed by up to $120 \mathrm{~km}$ of straight flight with the average error between the planned and actually flown flight line being about $50 \mathrm{~cm}$ (Rosa 2017a). The in-flight positioning accuracy of the OrbiSAR-2 sensor is $5 \mathrm{~cm}$ in three directions $(X, Y$ and $Z$ ). By comparison, the positioning accuracy in orbit of the TerraSAR-X satellite is $5 \mathrm{~cm}$ (eoPortal News, 2020).

SAR data acquisition used Turbo Commander aircraft, illustrated in Figure 5; equipment such as X-and P-band antennas and the OrbiSAR-2 radar system, both shown in Figure 6 . Figure 7 shows how the InSAR system processing was performed. 


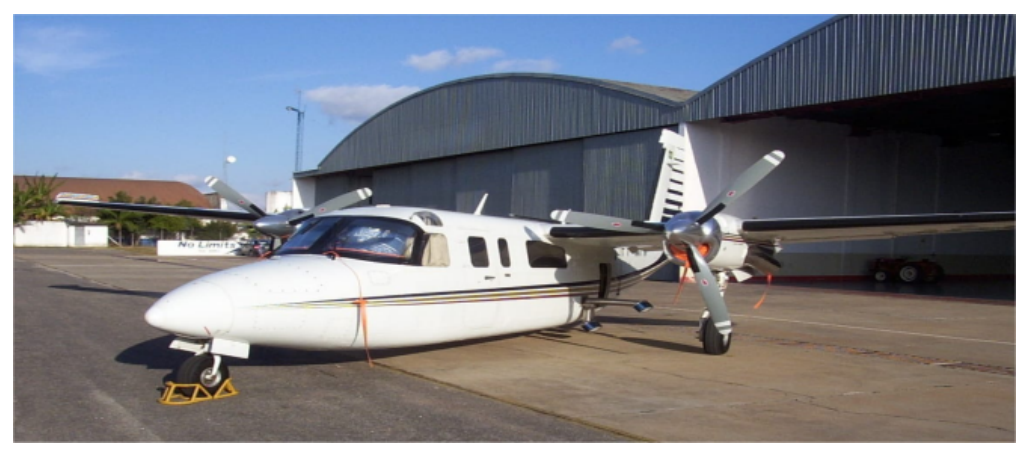

Source: Rosa (2015).

Figure 5: Turbo Commander aircraft used for InSAR system dataset acquisition.

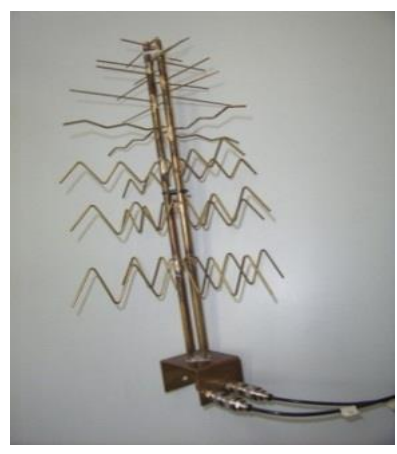

(a)

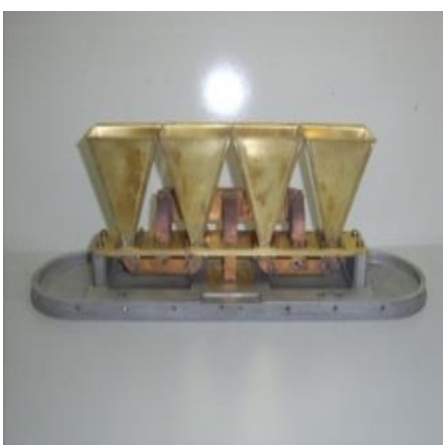

(b)

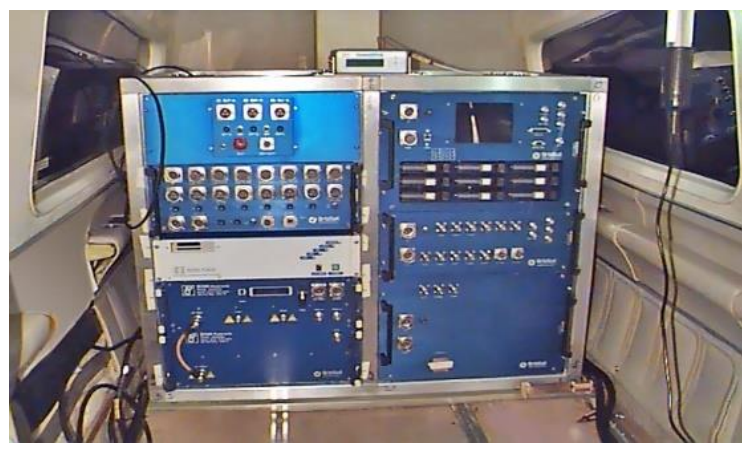

(c)

Source: Rosa (2015).

Figure 6: Equipment used to acquire the InSAR system dataset. a) P-band antenna; b) X-band antenna; and c) OrbiSAR-2 radar system.

The Table 1 presents the characteristics of $\mathrm{X}$ - and P-bands.

Table1: InSAR System X- and P-Bands Information.

\begin{tabular}{ccc}
\hline & X-Band & P-Band \\
\cline { 2 - 3 } Aircraft & Turbo-commander & Turbo-commander \\
\hline Flight Altitude & $6086.62 \mathrm{~m}$ & $6086.62 \mathrm{~m}$ \\
\hline Wave-length & $3.125 \mathrm{~cm}$ & $74.94 \mathrm{~cm}$ \\
\hline Carrier Frequency & $9.6 \mathrm{GHz}$ & $400.3 \mathrm{MHz}$ \\
\hline Bandwidth & $400 \mathrm{MHz}$ & $100 \mathrm{MHz}$ \\
\hline Polarization & $\mathrm{HH}$ & $\mathrm{HH}, \mathrm{HV}, \mathrm{VH} \mathrm{e} \mathrm{VV}$ \\
\hline Off-nadir Angle & $20^{\circ}$ & $10^{\circ}$ \\
\hline Swath Width & $14 \mathrm{~km}$ & $14 \mathrm{~km}$ \\
\hline Pixel Size & $1.5 \times 1.5 \mathrm{~m}$ & $1.5 \times 1.5 \mathrm{~m}$ \\
\hline DEM & $\mathrm{DSM}$ & $\mathrm{DTM}$ \\
\hline Radiometric resolution of orthoimaging & $0.5 \mathrm{~dB}$ & $0.5 \mathrm{~dB}$ \\
\hline DEM Altimetric Resolution & $0.50 \mathrm{~m}$ & $1.40 \mathrm{~m}$ \\
\hline Orthoimage pixel representation & $16 \mathrm{bits}$ & $16 \mathrm{bits}$ \\
\hline DEM pixel representation & $32 \mathrm{bits}$ & $32 \mathrm{bits}$ \\
\hline
\end{tabular}

Source: Rosa (2017b). 


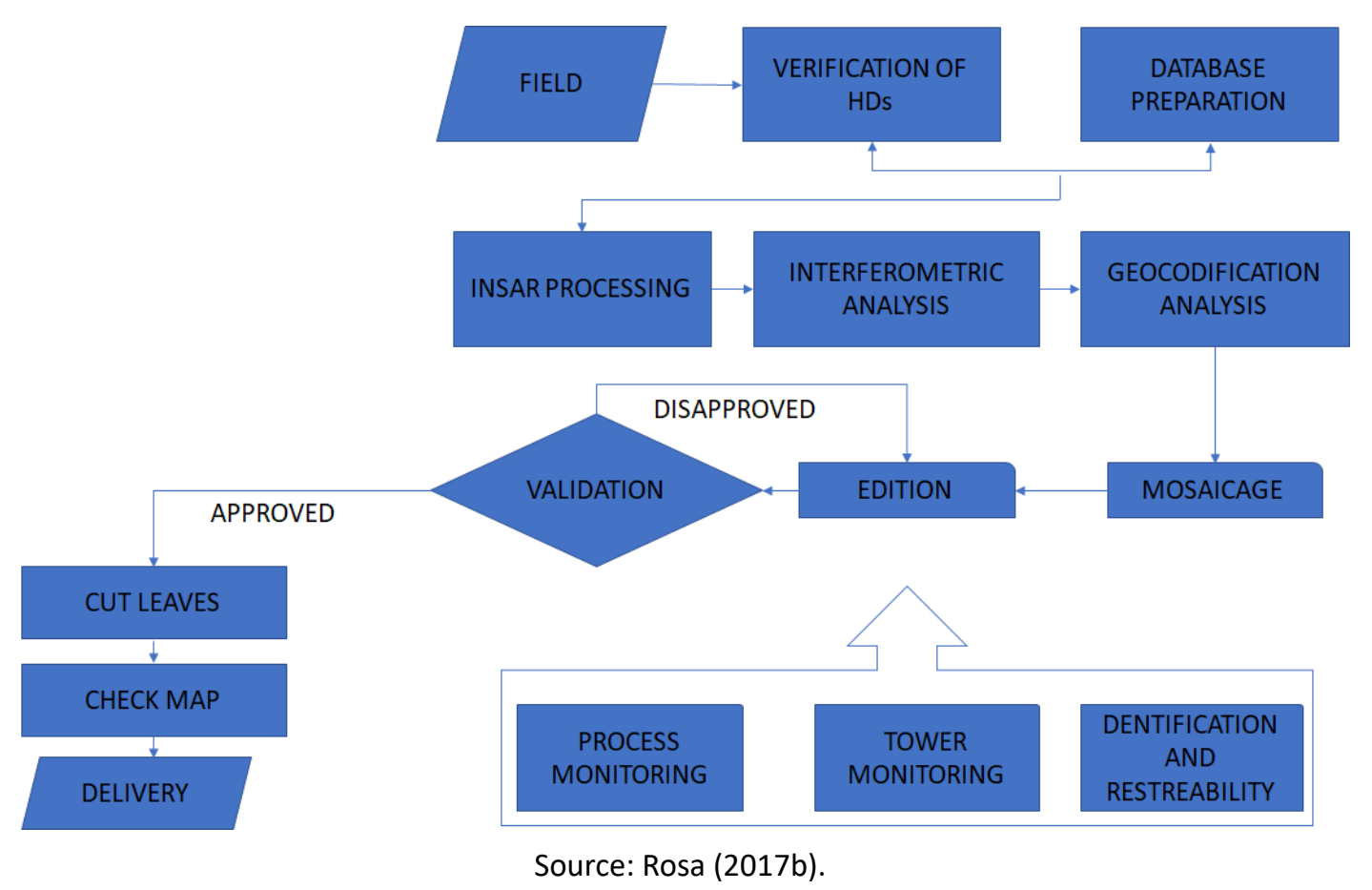

Figure 7: InSAR system process flowchart.

The control points distributed in the study area were collected by a team of six people using two GNSS L1 / L2 receivers (JAVAD TRIUMPH-1), on $19^{\text {th }}$ and $20^{\text {th }}$ January of 2019. These receivers were installed on tripods and leveling bases, and then the heights were measured at each tracked point. One receiver was located at the base SAT 93315 (Figure 8.a) that belongs to the Brazilian Geodetic System (SGB) and the other one collected the points, that is, used the static positioning method. The tracking time of the planialtimetric positional control points ranged from 25 to $50 \mathrm{~min}$ for each point (Figure 8.b), using the static positioning method. Data recording rate was 1 second with $15^{\circ}$ elevation mask. The data collected in the field were processed by the TOPCON TOOLS V.8.2 software (demo) with 95\% confidence level, obtaining coordinates in the Geodetic Reference System (SIRGAS2000) and Universal Transverse Mercator System (UTM) in the spindle $25^{\circ} \mathrm{S}$ at central meridian 33, and by Mapgeo2010 software to convert geometric altitude $h$, referring to ellipsoid, to orthometric $H$, referring to mean sea level (NMM). We used Mapgeo2010 for DTM processing, because SAR data acquisition was done in 2014.

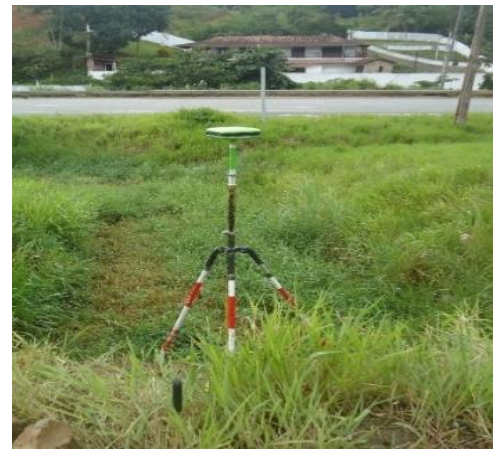

(a)

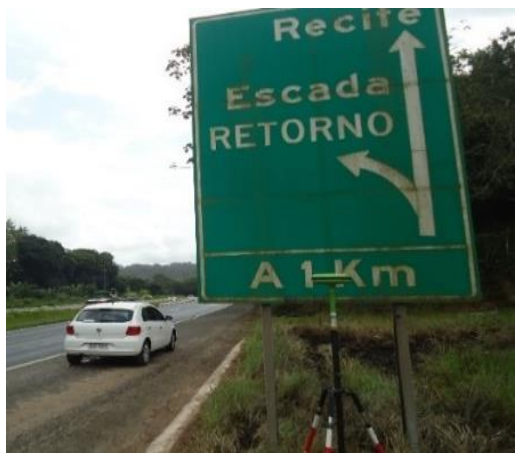

(b)

Source: Silva (2020)

Figure 8: GNSS receivers used for the acquisition of planialtmetric positional control points. a) receiver at base RN and b) at control point. 


\subsection{Planialtimetric Positional Control Points}

The choice of the planialtimetric positional control points selected in the orthoimage were based on four steps: the first step is the identification of features that could be used as positional control points in the field; in the second stage field, recognition is performed, and features are identified as metallic structures; the third step consists in the control points test, where these metallic features are acquired in the field and analyzes are performed verifying that their discrepancies found in the data are accepted according to the norms; therefore, in the fourth step, it is defined that the metal structures can be used as control points in SAR orthoimage, in which these points were tested and used in this research. We applied the Engineering Map Accuracy Standard (EMAS) (Ariza, 2002) test in the coordinates obtained in the field and thus found that there were systematic errors in the $X$ and $Y$ axis, i.e., there were trends in the $X$ and $Y$ axis of the analyzed points. This may have been caused by the receivers being too close to civil constructions such as lampposts, signposts, generating multipath in receiver signals. Regarding altimetry (Z), there was no trend.

\subsection{Control Point Validation - Statistical Accuracy Tests}

For positional validation, it is necessary to use the standard cartographic accuracy standardization PEC (Decree No. 89,817/1984) and PEC-PCD. These standards consider the expressions Standard Error, Standard Deviation, and Mean Square Error. Thus, they were used as Mean Square Error equals to Standard Deviation. Table 2 presents PEC and PEC-PCD classifications according to the categories (classes), in relation to the planimetric and altimetric coordinates.

Table 2: Classification according to PEC and PEC-PCD at 1: 10.000 scale.

\begin{tabular}{cccccc}
\hline \multirow{2}{*}{ classification (PEC) } & \multirow{2}{*}{ classification (PEC-PCD) } & \multicolumn{2}{c}{ Planimetric } & \multicolumn{2}{c}{ Altimetric } \\
\cline { 2 - 6 } & A & $2.80 \mathrm{~m}$ & $1.70 \mathrm{~m}$ & $1.35 \mathrm{~m}$ & $0.84 \mathrm{~m}$ \\
\hline A & B & $5.00 \mathrm{~m}$ & $3.00 \mathrm{~m}$ & $2.50 \mathrm{~m}$ & $1.67 \mathrm{~m}$ \\
\hline B & C & $8.00 \mathrm{~m}$ & $5.00 \mathrm{~m}$ & $3.00 \mathrm{~m}$ & $2.00 \mathrm{~m}$ \\
\hline C & D & $10.00 \mathrm{~m}$ & $6.00 \mathrm{~m}$ & $3.70 \mathrm{~m}$ & $2.50 \mathrm{~m}$ \\
\hline \multicolumn{5}{c}{ Source: DSG (2015). }
\end{tabular}

Aiming to know the accuracy of geographic data, statistical tests were applied, taking into consideration the hypotheses and the reliability of positional information, as presented in Table 3. The NMAS, ASPRS and NSSDA tests performed positional validation on the horizontal and vertical components, using comparison with a higher precision source (Ariza 2002). These tests require, at least, 20 points sampling of the product and a more accurate source, where:

$\mathrm{xt}_{\mathrm{i}}, \mathrm{yt}_{\mathrm{i}}, \mathrm{zt}_{\mathrm{i}}=$ Point coordinate on the $\mathrm{X}, \mathrm{Y}$ and $\mathrm{Z}$ axis over the most accurate terrain;

$\mathrm{xm}_{\mathrm{i}}, \mathrm{ym}_{\mathrm{i}}, \mathrm{zm}_{\mathrm{i}}=$ Point coordinate on $\mathrm{X}, \mathrm{Y}$ and $\mathrm{Z}$ axis obtained from Geographic Database (GD);

$R M S E=$ Root Mean Square Error; 
Table 3: Positional Accurancy Test

\begin{tabular}{|c|c|c|c|c|}
\hline Accuracy Test & \multicolumn{4}{|c|}{ steps } \\
\hline & \multirow{2}{*}{$\begin{array}{l}\text { 1. Calculate error for each } \\
\text { point on axes } X\left(e_{x i}\right), Y \\
\left(e_{y i}\right) \text { e } Z\left(e_{z i}\right) \text {, according } \\
\text { to Equations } 1,2 \text { and } 3 \text {, } \\
\text { respectively: }\end{array}$} & \multicolumn{3}{|c|}{$\begin{array}{l}\text { USGS determines that a maximum of } 10 \% \text { of the points verified in } \\
\text { your sample may have horizontal and vertical error, considering the } \\
\text { following ways: }\end{array}$} \\
\hline NMAS Test & & $\begin{array}{l}\text { 2. May have a } \\
\text { horizontal error } \\
\text { greater than } 0.08 \mathrm{~cm} \\
\text { (1/30 in) on maps } \\
\text { larger than } 1: 20,000 \\
\text { or } 0.05 \mathrm{~cm}(1 / 50 \mathrm{in}) \\
\text { for maps smaller than } \\
1: 20,000 \text {. But the } \\
\text { article considered the } \\
\text { Table - PEC- } 84 \text { and } \\
\text { PEC-PCD. }\end{array}$ & $\begin{array}{l}\text { 3. They may have an } \\
\text { error vertically larger } \\
\text { than half the interval } \\
\text { between contours. }\end{array}$ & $\begin{array}{l}\text { NOTE: The error in the } \\
\text { vertical dimension can } \\
\text { be corrected by varying } \\
\text { the position of the } \\
\text { points in an amount } \\
\text { equal to the acceptable } \\
\text { horizontal error. }\end{array}$ \\
\hline ASPRS Test & $\begin{array}{l}\text { 1. RMSE is calculated } \\
\text { for each component, for } \\
\text { example for component } \mathrm{X}, \mathrm{Y} \\
\text { and } \mathrm{Z} \text { - Equations } 4,5 \text { and } 6 \\
\text { respectively: } \\
R M S E_{x}=\sqrt{\frac{\sum_{i=1}^{n}\left(x t_{i}-x m_{i}\right)^{2}}{n}}\end{array}$ & $\begin{array}{l}\text { 2. Compliance with } \\
\text { the standard is verified } \\
\text { using the error limits } \\
\text { defined in the Test } \\
\text { Table, but the article } \\
\text { considered the Table - } \\
\text { PEC-84 and PEC-PCD. }\end{array}$ & $\begin{array}{r}\text { NOTE: The error in th } \\
\text { be corrected by vary } \\
\text { position of the points } \\
\text { the RN }\end{array}$ & $\begin{array}{l}\text { e vertical dimension can } \\
\text { ing in any direction the } \\
\text { by a value equal to twice } \\
\text { ASE limit. }\end{array}$ \\
\hline NSSDA Test & $\begin{array}{l}R M S E_{y}=\sqrt{\frac{\sum_{i=1}^{n}\left(y t_{i}-y m_{i}\right)^{2}}{n}}(5) \\
R M S E_{z}=\sqrt{\frac{\sum_{i=1}^{n}\left(z t_{i}-z m_{i}\right)^{2}}{n}}(6)\end{array}$ & $\begin{array}{l}\text { 2. It is calculated the } \\
\text { for the positional } \\
\text { component (XY) } \\
\text { according - Equation 7: } \\
R M S E_{r}=R M S E_{x}^{2}+R M S E_{y}^{2} \\
\text { (7) }\end{array}$ & $\begin{array}{l}\text { 3. The positional } \\
\text { precision coefficient } \\
\text { is calculated with } \\
95 \% \text { confidence, } \\
\text { depending on two } \\
\text { options: } \\
\text { a) in case that } \text { RMSE }_{\mathrm{x}}= \\
\text { RMSE }_{\mathrm{y}} \\
\text { Equation } 8: \\
\text { (8) } \\
\text { precision }_{r}=1.7308 * R^{2} M E_{r} \\
\text { b) in case that } \mathrm{RMSE}_{\mathrm{x}} \neq \\
\text { RMSE }_{\mathrm{y}} \\
\text { Equation } 9: \\
\text { precision }_{r}=1.22385 *\left(R M S E_{x}+\text { RMSE }_{\mathrm{y}}\right) \\
\text { (9) }\end{array}$ & $\begin{array}{l}\text { 4. It is calculated the } \\
\text { RMSE }_{z} \text { for component } Z \text {. } \\
\text { Calculate the } 95 \% \\
\text { confidence positional } \\
\text { accuracy coefficient for } \\
\text { component } Z \text { - Equation } \\
10 \text { : } \\
\text { precision }_{Z}=1.96 * R_{M S E_{Z}} \\
(10)\end{array}$ \\
\hline
\end{tabular}

\section{Results and Analysis}

This section presents the results obtained from the evaluated dataset, Orthoimage and the DTM, using tests whose confidence level varies from 90 to $95 \%$ in relation to the horizontal and vertical positioning of the inputs through the use of the standards effective in Brazil: PEC and PEC-PCD. 


\subsection{Control Points used in Planialtimetric Positional Validation}

The planned control points (Figure 9) used in the planialtimetric positional validation did not assume that the entire pixel was at the same coordinate, but that each part of the pixel has its coordinate, as sub-pixels. The control points were defined by observing pixel bursts of regular size and shape within the orthoimage. It was identified in the field that these explosions referred to lampposts, signposts or objects that had metal in their composition, taking care to avoid occlusion problems.

These control points should cover the study area and meet a minimum of 20 planialtimetric points so that the statistical tests could be applied. Thus, 22 points were selected within the study area as shown in Figure 9 and Table 4.

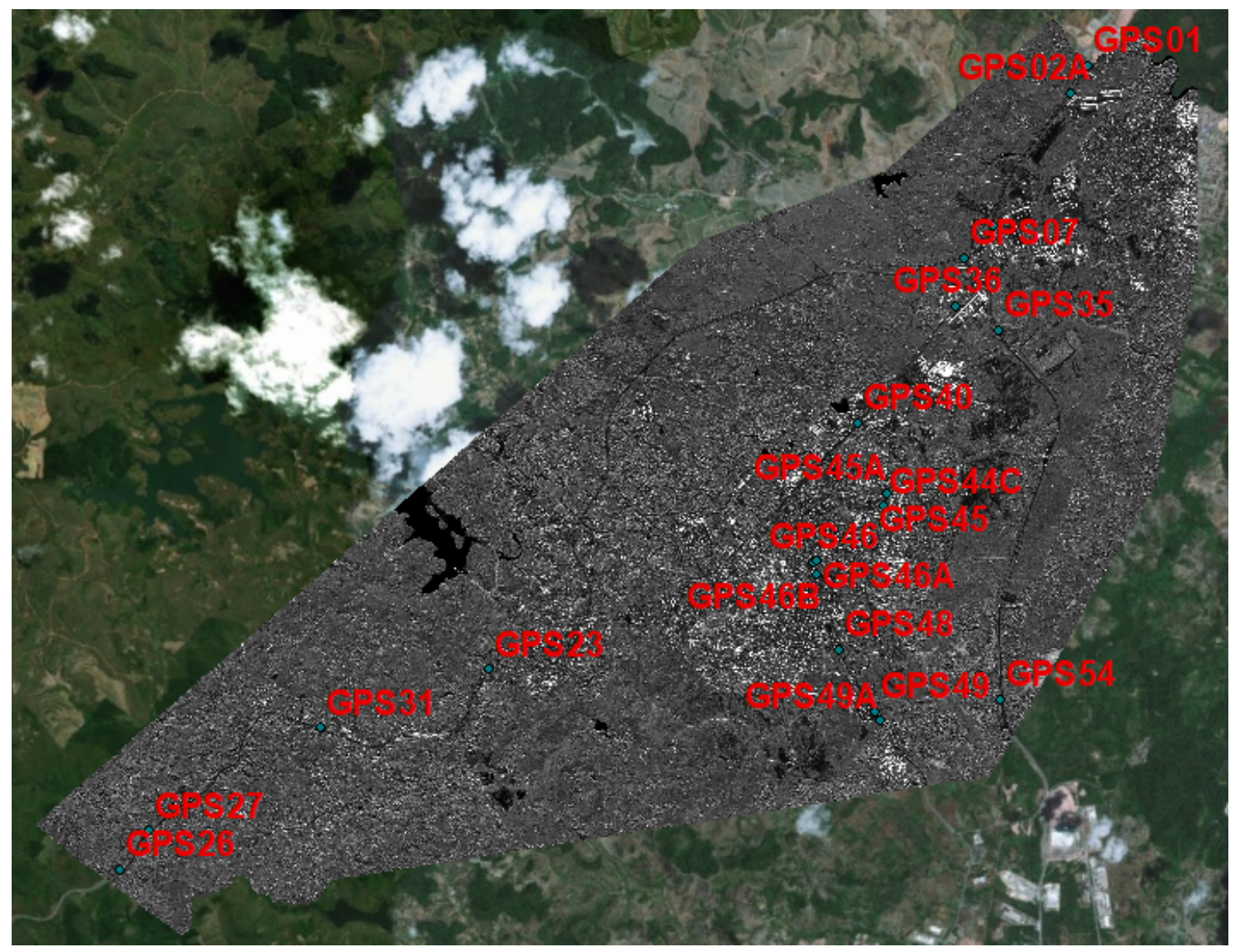

Source: Silva (2020)

Figure 9: Orthoimage with planialtimetric positional control points used in positional validation of the dataset: orthoimage and DTM.

The following coordinates of planialtimetric positional control points were obtained with GNSS L1/L2 receivers in the UTM coordinate system which are represented in Table 4. 
Table 4: The coordinates of the planialtimetric positional control point.

\begin{tabular}{|c|c|c|c|c|c|c|}
\hline \multirow[b]{2}{*}{ Points } & \multicolumn{4}{|c|}{ Planimetry } & \multicolumn{2}{|c|}{ Altimetry } \\
\hline & Ort - X (m) & GNSS - X (m) & Ort- $Y(m)$ & GNSS Y (m) & Ort-H (m) & GNSS - $\mathrm{H}(\mathrm{m})$ \\
\hline GPS46B & 276676.941 & 276675.978 & 9083208.027 & 9083208.205 & 11.418 & 12.099 \\
\hline GPS45A & 277627.708 & 277626.502 & 9084310.464 & 9084309.784 & 8.571 & 9.004 \\
\hline GPS40 & 277247.384 & 277245.636 & 9085277.073 & 9085279.099 & 11.076 & 10.769 \\
\hline GPS46 & 276633.550 & 276631.333 & 9083362.015 & 9083361.957 & 11.559 & 12.076 \\
\hline GPS48 & 276972.746 & 276973.283 & 9082166.096 & 9082165.931 & 10.564 & 11.077 \\
\hline GPS45 & 277455.517 & 277453.809 & 9083595.890 & 9083597.253 & 9.811 & 9.587 \\
\hline GPS54 & 279190.030 & 279188.697 & 9081474.888 & 9081476.615 & 13.853 & 14.420 \\
\hline GPS46A & 276657.362 & 276658.050 & 9083383.182 & 9083384.898 & 11.409 & 12.419 \\
\hline GPS49 & 277478.016 & 277477.898 & 9081311.098 & 9081310.279 & 10.968 & 11.660 \\
\hline GPS44C & 277587.234 & 277584.940 & 9084137.340 & 9084138.785 & 9.369 & 8.624 \\
\hline GPS36 & 278578.058 & 278577.506 & 9086889.660 & 9086891.502 & 20.178 & 19.009 \\
\hline GPS35 & 279169.833 & 279168.451 & 9086559.925 & 9086561.455 & 16.881 & 16.481 \\
\hline GPS49A & 277545.306 & 277544.288 & 9081182.373 & 9081182.625 & 9.453 & 11.723 \\
\hline GPS28 & 267792.392 & 267794.856 & 9079978.014 & 9079982.820 & 69.591 & 71.447 \\
\hline GPS23 & 272154.851 & 272153.410 & 9081891.749 & 9081892.930 & 51.942 & 53.172 \\
\hline GPS26 & 267084.365 & 267081.929 & 9079142.987 & 9079142.843 & 75.949 & 74.111 \\
\hline GPSO6 & 279093.695 & 279094.479 & 9087989.679 & 9087990.843 & 30.322 & 30.388 \\
\hline GPS27 & 267469.335 & 267466.553 & 9079672.419 & 9079672.396 & 61.954 & 63.930 \\
\hline GPS07 & 278706.344 & 278706.190 & 9087548.353 & 9087547.879 & 15.447 & 15.347 \\
\hline GPS02A & 280168.963 & 280167.668 & 9089818.483 & 9089820.000 & 6.426 & 6.298 \\
\hline GPS31 & 269829.952 & 269828.604 & 9081089.266 & 9081091.079 & 78.057 & 76.687 \\
\hline GPS33 & 271439.680 & 271436.244 & 9080985.284 & 9080985.921 & 62.004 & 59.483 \\
\hline
\end{tabular}

where:

Ort $-X$ e Ort $-Y=$ Coordinates of the point on the $X$ and $Y$ axis obtained from the Map;

Ort $-\mathrm{H}=$ Point coordinates on the $\mathrm{Z}$ axis relative to the orthometric altitude of the map;

GNSS $-X$ e GNSS $-Y=$ Point coordinates on the $X$ and $Y$ axis of the field acquired point with GNSS receivers;

GNSS - H = Z-axis point coordinate for orthometric altitude in field with GNSS receivers;

Accordingly, with this result presented in the Table 4, the planialtimetric positional validation of the Orthoimage and DTM was performed.

At each planned point there were burst (explosion) of pixels that were identified in the field as a metal structure. Thus, for better visualization, the orthoimage was zoomed to show where the point and the photo of the day of its acquisition is located, as shown in Figure 10. 


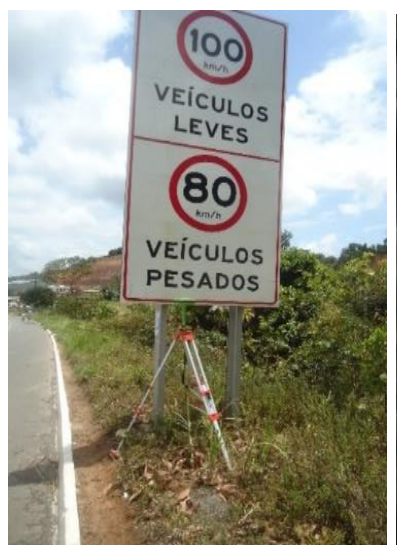

(a)

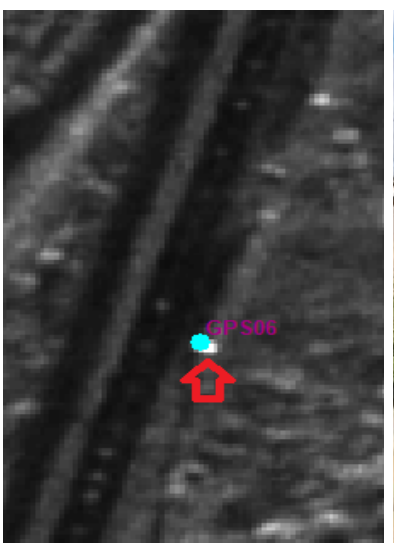

(b)

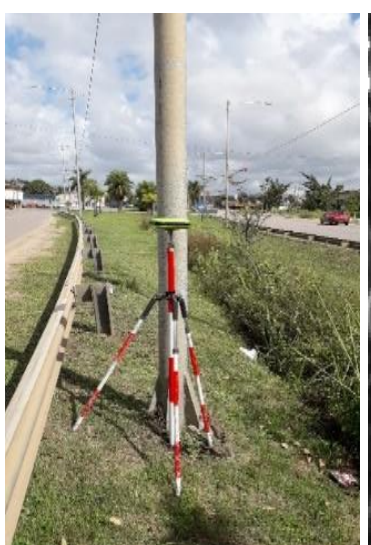

(c)

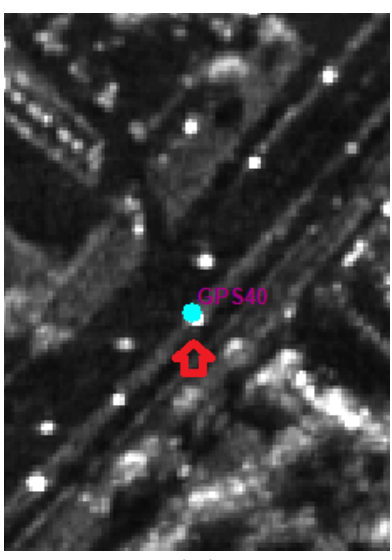

(d)

Source: Silva (2020)

Figure 10: Planialtimetric positional control points (photograph taken on the day of field collection and corresponding pixel blast location in the orthoimage): a) GPS06 Photo; b) GPS06 Orthoimage; c) GPS40 Photo; and d) GPS40 Orthoimage.

\subsection{Control Point Validation in Planialtimetric Positional Validation Tests}

The planialtimetric positional validation of the orthoimage and DTM dataset was performed as follows: first the discrepancies between the control point acquired by GNSS and that obtained in the orthoimage were found; then, the statistical tests NMAS, ASPRS and NSSDA were applied, together with the Brazilian standardization of cartographic accuracy standard.

\subsubsection{NMAS Test}

The discrepancies calculated with respect to the $X, Y$ and $Z$ axis according to equations 1,2 and 3 are presented in Table 5.

According to PEC (Table 2), a maximum of $10 \%$ of the sample points may have a horizontal error greater than $5 \mathrm{~m}$ and a vertical error greater than $3 \mathrm{~m}$ on 1: 10.000 scale maps. For PEC-PCD, for a map of the same scale, a maximum of $10 \%$ of the sample points may have a horizontal error greater than $2.80 \mathrm{~m}$ and a vertical error greater than $1.70 \mathrm{~m}$. Thereby, Table 6 shows the result of horizontal and vertical accuracy with respect to PEC and PEC-PCD.

Table 5: Control point discrepancies obtained by calculations with equations 1, 2 and 3.

\begin{tabular}{cccccccc}
\hline Points & $\mathbf{( m )}$ & $\mathbf{( m )}$ & $\mathbf{( m )}$ & Points & $\mathbf{( m )}$ & $\mathbf{( m )}$ & $\mathbf{( m )}$ \\
\hline GPS46B & -0.963 & 0.177 & 0.681 & GPS35 & -1.382 & 1.529 & -0.399 \\
\hline GPS45A & -1.206 & -0.680 & 0.433 & GPS49A & -1.018 & 0.252 & 2.270 \\
\hline GPS40 & -1.749 & 2.026 & -0.307 & GPS28 & 2.464 & 4.806 & 1.856 \\
\hline GPS46 & -2.217 & -0.057 & 0.517 & GPS23 & -1.441 & 1.181 & 1.230 \\
\hline GPS48 & 0.536 & -0.164 & 0.513 & GPS26 & -2.436 & -0.144 & -1.838 \\
\hline GPS45 & -1.708 & 1.363 & -0.224 & GPS06 & 0.784 & 1.164 & 0.066 \\
\hline GPS54 & -1.333 & 1.727 & 0.567 & GPS27 & -2.782 & -0.023 & 1.976 \\
\hline GPS46A & 0.687 & 1.716 & 1.011 & GPS07 & -0.154 & -0.474 & -0.100 \\
\hline GPS49 & -0.118 & -0.819 & 0.692 & GPS02A & -1.296 & 1.517 & -0.127 \\
\hline GPS44C & -2.293 & 1.445 & -0.745 & GPS31 & -1.348 & 1.813 & -1.369 \\
\hline GPS36 & -0.552 & 1.843 & -1.169 & GPS33 & -3.437 & 0.637 & $-2,521$ \\
\hline \hline
\end{tabular}


Regarding the NMAS test, the obtained values indicate that the points in the planimetry $(X, Y)$ and altimetry $(Z)$ were classified in class " $\mathrm{A}$ " in relation to the PEC, that is, $90 \%$ of the studied points are in this classification, planimetry and altimetry which fully meets the PEC because the manufacture of this set was based on this PEC.

Regarding the PEC-PCD, it was observed that $90 \%$ of the studied points in relation to the planimetry, obtained the class " $\mathrm{A}$ ", and in relation to the altimetry, the class " $\mathrm{B}$ ". It is also observed that the differences between the calculated standard errors and those of this standardization are closer, suggesting that the accuracy of the studied data is smaller. The dataset used was acquired in 2014, therefore, one year before the PEC-PCD release. The creation of these maps used in the study was certainly not based on the standards designated by the PEC-PCD. Therefore, the use of this data in practical applications involving altimetry, such as slope stability and landslides, should be checked in the field.

In addition, in relation to planimetry, according to Ariza (2002), the USGS recommends that, at most $10 \%$ of the sample points can have a horizontal error greater than $0.08 \mathrm{~cm}(1 / 30 \mathrm{in})$ on maps of scale greater than 1 : 20,000 or $0.05 \mathrm{~cm}(1 / 50 \mathrm{in})$ for maps with a scale less than 1: 20,000 . And the altimetry at a maximum of $10 \%$ of the selected numbers in the sample may have a vertical error greater than half the interval between the contours.

Analyzing the values $\mathrm{e}_{\mathrm{xi}}$ and $\mathrm{e}_{\mathrm{yi}}$ in Table 6, only two points are valid, one at the GPS46 point on the $Y$ axis and the other at the GPS27 point on the $X$ axis. Therefore, the SAR dataset analyzed here does not meet the value provided by the USGS. In relation to the $e_{z i}$ value in Table 6 , of the 22 points of the sample, it was found that only 1 point is above $2.50 \mathrm{~m}$ while 21 points were up to $2.50 \mathrm{~m}$, representing $95.46 \%$ of the sample.

Table 6: Analysis of the planialtimetric positional control points according to PEC and PEC-PCD.

\begin{tabular}{|c|c|c|c|c|c|c|c|c|c|}
\hline Points & (m) & PEC & PEC - PCD & $(\mathrm{m})$ & PEC & PEC -PCD & $(m)$ & PEC & PEC -PCD \\
\hline GPS46B & -0.963 & A & A & 0.177 & $\mathrm{~A}$ & A & 0.681 & A & A \\
\hline GPS45A & -1.206 & A & $A$ & -0.680 & $A$ & $A$ & 0.433 & $A$ & $A$ \\
\hline GPS40 & -1.749 & $A$ & $A$ & 2.026 & A & A & -0.307 & A & A \\
\hline GPS46 & -2.217 & A & A & -0.057 & $A$ & $A$ & 0.517 & A & $A$ \\
\hline GPS48 & 0.536 & $A$ & $A$ & -0.164 & $A$ & $A$ & 0.513 & $A$ & $A$ \\
\hline GPS45 & -1.708 & A & $\mathrm{A}$ & 1.363 & A & A & -0.224 & $A$ & A \\
\hline GPS54 & -1.333 & A & A & 1.727 & A & $\mathrm{A}$ & 0.567 & A & A \\
\hline GPS46A & 0.687 & A & A & 1.716 & A & A & 1.011 & $A$ & $A$ \\
\hline GPS49 & -0.118 & $\mathrm{~A}$ & $\mathrm{~A}$ & -0.819 & $A$ & $A$ & 0.692 & $\mathrm{~A}$ & $A$ \\
\hline GPS44C & -2.293 & A & $A$ & 1.445 & $A$ & $A$ & -0.745 & A & $A$ \\
\hline GPS36 & -0.552 & A & A & 1.843 & A & A & -1.169 & A & A \\
\hline GPS35 & -1.382 & A & $\mathrm{A}$ & 1.529 & $A$ & $A$ & -0.399 & A & $A$ \\
\hline GPS49A & -1.018 & A & A & 0.252 & A & A & 2.270 & A & $\mathrm{B}$ \\
\hline GPS28 & 2.464 & A & A & 4.806 & A & B & 1.856 & A & B \\
\hline GPS23 & -1.441 & A & $A$ & 1.181 & $A$ & $A$ & 1.230 & $A$ & $A$ \\
\hline GPS26 & -2.436 & $\mathrm{~A}$ & $A$ & -0.144 & A & A & -1.838 & A & $\mathrm{B}$ \\
\hline GPSO6 & 0.784 & A & $A$ & 1.164 & $A$ & $A$ & 0.066 & A & $A$ \\
\hline GPS27 & -2.782 & A & A & -0.023 & A & $A$ & 1.976 & A & B \\
\hline GPSO7 & -0.154 & A & A & -0.474 & $\mathrm{~A}$ & $\mathrm{~A}$ & -0.100 & $A$ & $A$ \\
\hline GPS02A & -1.296 & A & A & 1.517 & A & A & -0.127 & A & A \\
\hline GPS31 & -1.348 & A & A & 1.813 & A & A & -1.369 & A & A \\
\hline GPS33 & -3.437 & A & B & 0.637 & $A$ & $A$ & $-2,521$ & $A$ & B \\
\hline
\end{tabular}




\subsubsection{ASPRS Test}

In this test, the discrepancies calculated with respect to the $X, Y$ and $Z$ axis according to equations 1,2 and 3 are presented in Table 3. These data were applied in the computation of RMSE (equations 4, 5 e 6).

According to PEC classification, the RMSE is in class " $A$ " on all axis, that is below $3.00 \mathrm{~m}$. Regarding the PEC$P C D$ classification, the class " $A$ " was obtained in the planimetry, i.e., below $1.70 \mathrm{~m}$ and class " $\mathrm{B}$ " in the altimetry, that is, below $1.67 \mathrm{~m}$. Likewise, regarding this statistical test, the same is true as in the previous case. The development of digital technologies provides improved accuracy in the planimetric and altimetric maps which is verified when applying the statistical tests to the acquired data.

Compliance with the standard is verified using the error limits defined in Table 7.

Table 7: ASPRS Test Accuracy Requirements.

\begin{tabular}{cc}
\hline Requirements for planimetric accuracy in $\mathrm{X}$ or $\mathrm{Y}$ coordinates for well-defined points on class I maps \\
\hline Product Scale & Limit $R M S E(\mathrm{~m})$ \\
\hline $1: 10.000$ & 2.50 \\
\hline
\end{tabular}

Source: Ariza (2002)

Looking at Table 7, it looks like, for a scale of 1: 10,000, that the limit RMSE is up to $2.50 \mathrm{~m}$. Therefore, the SAR dataset according to the results obtained $R M S E_{x}$ and $R M S E_{y}$ are lower than the limit $R M S E$, therefore, they are in accordance with the precision requirements of ASPRS.

In relation to altimetry, the RMSE is considered $1 / 3$ of the interval between the contour lines, so the RMSE for this case will be $1,667 \mathrm{~m}$. Soon $R M S E_{z}$ meets the ASPRS test.

\subsubsection{NSSDA Test}

In this test, the discrepancies calculated with respect to the $X$ and $Y$ axis, according to equations 1 and 2 , are presented in Table 3. These data were applied in the computation of RMSE (equations 4 e 5).

Using equation 7 with the components obtained above $\left(R M S E_{x}\right.$ and $\left.R M S E_{y}\right)$, the result achieved from for the $X$ and $Y$ axis is:

$R M S E_{r}=1.802 \mathrm{~m} ;$

With the result obtained from and analyzing Table 3 on the use of equations 8 and 9, it used equation 9 because $R M S E_{x} R M S E_{y}$ for the positional precision coefficient of $95 \%$ confidence, the result obtained was:

Precision $_{r}=3.118 \mathrm{~m}$;

The discrepancy is calculated to the $Z$ axis according to equation 3 presented in Table 3. This data is applied in the computation of RMSE (equation 6). The result obtained from the RMSE on the $Z$ axis was:

RMSE $_{z}=1.177 \mathrm{~m}$.

With the result obtained from $R M S E_{z^{\prime}}$ it used the equation 10. the result obtained was:

Precision $_{z}=2.306 \mathrm{~m}$

According to PEC classification in relation to the RMSE $E_{x}$ and $R M S E_{y}$ analyzed in the ASPRS test, they had PEC-A classification in PEC in all axis $(X, Y, Z)$ because the standard deviation values are below $3.0 \mathrm{~m}$ in relation to planimetry and $1.67 \mathrm{~m}$ in relation to altimetry. In relation to PEC-PCD obtained PEC-A on $(X, Y)$, that is, the standard deviation is below $1.70 \mathrm{~m}$ and PEC-B axis on the $Z$ axis, that is, the standard deviation is below $1.67 \mathrm{~m}$. The ASPRS test also analyzes 
the standard deviation of the distance between two points (Orthoimage and GNSS) and provides its accuracy of the distance between these two points, enabling the user to have standard deviation information and the accuracy of the distance between these two points.

The NSSDA test analyzes the sample with a 95\% confidence level showing the cartography quality index in the real units of the terrain and also allows professionals to decide the level of confidence, although in this article, $95 \%$ confidence level was used for the NSSDA test.

The set of altimetric data, with a $95 \%$ confidence level, was accurate to $2.306 \mathrm{~m}$. The NSSDA test allows professionals to determine the level of confidence they want in the analyzed cartographic works. Therefore, according to the found precision and the required precision for the present article, these data are favorable in relation to the altimetric positional quality.

Finally, Table 8 summarizes all obtained results.

Table 8: Summary of results obtained in all applied tests.

\begin{tabular}{cccc}
\hline & & Test & \\
\cline { 2 - 4 } & NMAS & ASPRS & NSSDA \\
\hline Valid points (altimetry) & $95.46 \%$ & - & - \\
\hline$R M S E_{x}$ & - & $1.317 \mathrm{~m}$ & $1.317 \mathrm{~m}$ \\
\hline$R M S E_{y}$ & - & $1.231 \mathrm{~m}$ & $1.231 \mathrm{~m}$ \\
\hline$R M S E_{z}$ & - & $1.177 \mathrm{~m}$ & $1.177 \mathrm{~m}$ \\
\hline$R M S E_{r}$ & - & - & $1.802 \mathrm{~m}$ \\
\hline Precision $_{r}$ & - & - & $3.118 \mathrm{~m}$ \\
\hline Precision $_{z}$ & - & - & $2.306 \mathrm{~m}$ \\
\hline
\end{tabular}

The results presented in this article show, in relation to the positional accuracy control tests, that:

- NMAS and ASPRS tests, according to Ariza (2002), to perform dataset analysis, use the discrepancy formulas on each coordinate axis (X, $\mathrm{Y}$ and $\mathrm{Z}$ ). These discrepancies are classified in accordance with current Brazilian standards (PEC e PEC-PCD).

- The NMAS test applied the levels of positional precision provided by Ariza (2002) in accordance with USGS, which notes that the precision is used in millimeter to validate data quality. This test is also recommended to tasks that need millimeter precision quality.

- The ASPRS test according to Ariza (2002) presented in Table 7, shows with scale and precision that each sample must be analyzed, ranging from millimeter to meter, this will depend on the scale value. This test shows that if the scale increases, more precision is needed in the analyzed sample.

- The NSSDA test, according to Ariza (2002), also uses RMSE on each coordinate axis (X, Y, and Z) in its steps, but it also provides standard deviation information and precision in relation to the distance between GNSS-supplied data and inputs (Orthoimage and DTM). According to Ariza (2002), accuracy will depend on the user's choice, thus allowing professionals to determine the level of confidence they want in the analyzed cartographic works. This article used a 95\% confidence level for the validation of SAR data, thus obtaining values that are classified according to Brazilian standards. This test was also used by Iordan \& Popescu (2015) in a LiDAR (Light Detection and Ranging) dataset, where the authors also used the $95 \%$ confidence level to validate the data obtained in different types of soil and obtained a $21.5 \mathrm{~cm}$ RMSE result, while in this article we achieved $1.77 \mathrm{~m}$. However, the authors used LiDAR with a resolution of 50 points per square meter and vertical precision of 5 to $15 \mathrm{~cm}$, while we used SAR data with pixel 
resolution $1.5 \times 1.5 \mathrm{~m}$ and precision $1.5 \mathrm{~m}$.

For the positional validation of orthoimage and DTM inputs, a more accurate source was used to acquire the control points: the GNSS receivers, using the static method in all control points and, for georeferencing, the Brazilian Geodetic System (SGB).

The use of GNSS receivers to collect positional control points is quite common for verifying the information generated in the SAR dataset, as presented by the authors Souza Filho and Paradella (2005), Oliveira et al. (2011), Capaldo et al. (2015), Paradella et al. (2015), Guimarães et al. (2018) and Guimarães et al. (2020). Comparing the results obtained with other works cited and found in the literature, we observed that the most common is to work with natural features as control points for Digital Elevation Model (DEM) validation. We also noted that vertical errors are always analyzed for quality requirements according to the project scale, using SAR data on different acquisition platforms, with varying pixel sizes and resolutions. Besides, when comparing the research conducted by Souza Filho and Paradella (2005), Oliveira et al. 2011, Capaldo et al. (2015), Paradella et. al. (2015), Guimarães et. al. (2018) and Guimarães et al. (2020), it seems that the control points used have very different characteristics from those chosen by Silva (2020), having obtained though, very similar results. This proves that these points proposed in this study are sufficient for planialtimetric positional validation of the used SAR dataset.

\section{Conclusions and Recommendations}

We concluded that the datasets (orthoimage, in relation to planimetry, and DTM, regarding the altimetry, from the InSAR system) were positionally validated, using the statistical tests cited in the article. We obtained the following results: the classification according to PEC was class " $\mathrm{A}$ " in relation to planialtimetry and PEC-PCD, class " $\mathrm{A}$ " in planimetry and class " $\mathrm{B}$ " in altimetry. These results prove we can use the proposed targets (traffic signs and lamppost) as control points for 1:10,000 scale.

Finally, it is important to highlight that this work made it possible to validate, using different statistical tests, the orthoimage and DTM from InSAR inputs, which shall be used to make products for the geotechnical area, such as slope maps, shaded relief, among others.

\section{REFERENCES}

Arcanjo, D. R. and Anjos, C. S. 2019. Análise da acurácia posicional planimétrica de imagem orbital do sensor PAN/ CBERS-4. XIX Simpósio Brasileiro de Sensoriamento Remoto, pp. 2806-2809.

Ariza, F. J. 2002. Calidad en la Producción Cartográfica. 1st ed. Madrid: RAMA.

Capaldo, P., Nascetti, A., Porfiri, M., Pieralice, F., Fratarcangeli, F., Crespi, M. and Toutin, T. 2015. Evaluation and comparison of different radargrammetric approaches for Digital Surface Models generation from COSMO-SkyMed, TerraSAR-X, RADARSAT-2 imagery: Analysis of Beauport (Canada) test site. Journal of Photogrammetry and Remote Sensing (ISPRS), pp. $60-70$.

Curlander, J. C. and Mcdonough, R. N. 1992. Synthetic Aperture Radar: Systems and Signal Processing. 1st ed. Nova Jersey: Wiley-Blackwell.

DSG - Brazilian Army Geographic Service. 2015. Technical Specification for Vector Geospatial Data Acquisition (ETADGV). [pdf] Brasília: Brazilian Army Geographic Service. Available at: <http://www.geoportal.eb.mil.br/portal/ images/PDF/ADGV_Defesa-Forca_Terrestre_2015.pdf> [Accessed 01 November 2016]. 
DSG - Brazilian Army Geographic Service. 2015. Technical Specification for Geospatial Data Quality Control (ET-CQDG). [pdf] Brasília: Brazilian Army Geographic Service. Available at: < http://www.geoportal.eb.mil.br/portal/images/ PDF/ET_CQDG_1a_edicao_2016.pdf> [Accessed 01 November 2016].

eoPortal News. 2020. TSX (TerraSAR-X) Mission. [online] updated March 4, 2020. Available at: https://directory. eoportal.org/web/eoportal/satellite-missions/t/terrasar-x.

Farias, J. L. P., Merêncio, I. and Vieira, C. A. O. 2018. Avaliação da acurácia cartográfica planimétrica do produto gerado a partir de aeronave remotamente pilotada (RPA). In.: COBRAC - 2018, 13o Congresso Brasileiro de Cadastro Técnico Multifinalitário e Gestão Territorial, Florianópolis - SC, 2018.

Franceschetti, G. and Lanari, R. 2018. Synthetic Aperture Radar Processing. 2nd ed. Boca Raton: CRC Press.

Gaboardi, C. and Lübeck, D. 2016. Precisão altimétrica de modelo digital do terreno sob a vegetação obtido por interferometria de radar de abertura sintética de banda P. Revista Brasileira de Geografia, pp. 67-81.

Galo, M. and Camargo, P. O. 1994. Utilização do GPS no controle de qualidade de cartas. In.: COBRAC - 1994, $1^{\circ}$ Congresso Brasileiro de Cadastro Técnico Multifinalitário. Tomo II, p. 41-48, Florianópolis - SC, 1994.

Guimarães, U. S., Galo, M. L. B. T., Narvaes, I. S. and Silva, A. Q. 2020. Cosmo-SkyMed and TerraSAR-X datasets for geomorphological mapping in the eastern of Marajó Island, Amazon coast. Geomorphology, 350, pp.106934.

Guimarães, U. S., Narvaes, I. S., Galo, M. L. B. T., Silva, A. Q. and Camargo, P. O. 2018. Radargrammetric approaches to the flat relief of the amazon coast using COSMO-SkyMed and TerraSAR-X datasets. ISPRS Journal of Photogrammetry and Remote Sensing, pp 284-296.

Iordan, D. and Popescu, G. 2015. The accuracy of lidar measurements for the different land cover categories. Scientific Papers. Series E. Land Reclamation, Earth Observation \& Surveying, Environmental Engineering, 4, pp.158-164.

Maranhão, V. C. 2013. Modelagem e controle de qualidade de uma infraestrutura de dados espaciais para o estado de Pernambuco. Master's Thesis - Federal University of Pernambuco (UFPE).

Milagros, Y. 2018. Aplicación de test para control de calidad posicional al producto cartográfico obtenido mediante vuelo aerofotogramétrico con VANT. Thesis to opt for a professional diploma. Vicerrectorado de Investigación UNFV).

Moreira Neto, J. R. 1992. Bewegungsextraktionsverfahren für Radar mit Synthetischer Apertur. PhD. Technique Universität München.

Oliveira, C. G. O., Paradella, R. W. and Silva, A. Q. 2011. Assessment of radargrammetric DSMs from TerraSAR-X Stripmap images in a mountainous relief area of the Amazon region. Journal of Photogrammetry and Remote Sensing (ISPRS), pp. 67-72.

Paradella, W. R., Ferretti, A., Mura, J. C., Colombo, D., Gama, F. F., Tamburini, A., Santos, A. R., Novali, F., Galo, M., Camargo, P. O., Silva, A. Q., Silva, G. G., Silva, A. and Gomes, L. L. 2015. Mapping surface deformation in open pit iron mines of Carajás Province (Amazon Region) using an integrated SAR analysis. Engineering Geology, pp 61-78.

Pereira, T. A. J. and Nero, M. A. 2015. Controle de qualidade posicional de imagem quick bird ortorretificada no spring de acordo com o PEC-PCD. XVII Simpósio Brasileiro de Sensoriamento Remoto, pp. 2133-2140.

ROSA, R. A. S. 2004. Desenvolvimento de um Algoritmo de Desdobramento de Fase para Radar de Imagens Interferométrico Aerotransportado Utilizando uma Linha de Base. Trabalho de Conclusão de Curso. (Graduação) Instituto Tecnológico de Aeronáutica (ITA).

Rosa, R. A. S. 2015. Minicurso: Percepción Remota SAR - CVC. Conference: Corporación Autónoma Regional del Valle del Cauca (CVC) [pdf]. Available at: https://www.researchgate.net/publication/322695025_Minicurso_Percepcion_ Remota_SAR_-_CVC. [Accessed 06 November 2016].

Rosa, R. A. S. 2017a. Detecção de mudanças em imagens SAR multitemporais das bandas X e P. Tese de DoutoradoInstituto Tecnológico de Aeronáutica (ITA). 
Rosa, R. A. S. 2017b. Minicurso: Introdução ao Sensoriamento Remoto por Radar - GEGEP/UFPE [pdf]. Available at: https://www.researchgate.net/publication/322664777_Minicurso_Introducao_ao_Sensoriamento_Remoto_por_ Radar_-_GEGEPUFPE. [Accessed 08 January 2018].

Silva, G. P. 2020. Uma metodologia no controle de qualidade de produtos de sensoriamento remoto por radar e sua importância no mapeamento geológico-geotécnico. Doctoral Thesis - Federal University of Pernambuco (UFPE).

Souza Filho, P. W. M. and Paradella, W. R. 2005. Use of RADARSAT-1 fine mode and Landsat-5 TM selective principal component analysis for geomorphological mapping in a macrotidal mangrove coast in the Amazon Region. Canadian Journal of Remote Sensing, 31(3), pp 214-224. 